Boston University School of Law

Scholarly Commons at Boston University School of Law

Faculty Scholarship

1992

Changing the Consent Rules for Desert Storm

George J. Annas

Follow this and additional works at: https://scholarship.law.bu.edu/faculty_scholarship

Part of the Military, War, and Peace Commons 
tongue-twisters such as aditus ad antrum or ramus sympathicus ad ganglia ciliae rarely appear in Nomina Anatomica, ${ }^{*}$ having been long retired by the streamlined genitive - i.e., falx cerebri and crista galli. Furthermore, the paper-sparing use of the locative "porcellus fori" (at market) preserves the rhyme scheme established by the locative $p$. domi (at home), which I suggested in my original letter.

John L. Phillips New Haven, CT $06510 \quad$ Yale University School of Medicine

*International Anatomical Nomenclature Committee. Nomina anatomica. 3rd ed. Amsterdam: Excerpta Medica, 1966.

To the Editor: In reference to the points recently raised by the Thomases, I offer the following. First, in the case of a verb implying motion associated with domum ("homeward"), I wish to assure the Classics Department of Harvard University that the phrase is indeed vectoral. Anyone who has ever had the occasion to go "wee, wee, wee, all the way home" can attest not only to the motion involved but to the direction as well. Second, in regard to the personal condition referred to as porcocapitic, I will cite the old lay adage, Quam facile est judicare aegroto non viso! (How easy it is to diagnose, not having seen the patient! [Barnard L: personal communication]). Finally, to address the chiding for the "i" missing from micturens (micturiens), I can only say that I am sure that credit for the extra " $i$ " is freely given, since all

\section{LEGAL ISSUES IN MEDICINE}

\section{CHANGING THE CONSENT RULES FOR DESERT STORM}

George J. Annas, J.D., M.P.H.

SHORTLY before the beginning of Operation Desert Storm, during Desert Shield, the U.S. military sought a waiver of requirements for informed consent for the use of investigational drugs and vaccines on our troops in the Persian Gulf. The danger of chemical and biologic warfare was seen as demanding this waiver, although the Nuremberg Code, other codes of medical ethics, and respect for the human rights of American soldiers seemed to caution against it. One year later it seems reasonable to review this decision. The legal maneuvering to revise consent regulations for wartime conditions provides a case study that highlights three separable issues: how easily the line between therapy and experimentation can become blurred; the differences between law and ethics; and the ethical obligations of physicians when the interests of their patients conflict with the interests of their employer.

\section{The Nuremberg Code and the U.S. Army}

The Nuremberg Code was promulgated by U.S. judges sitting under the authority of the U.S. Army at Nuremberg, Germany, in 1947..$^{1,2}$ The defendants in the Doctors' Trial were charged with war crimes and crimes against humanity for performing both lethal and nonlethal experiments on prisoners. Most were know that it is in the nature of our friend the pig to be "sooey generous."

Milwaukee, WI 53211

David L. Sovine, M.D. Columbia Hospital

\section{WEEP}

Weary are we, we end

At the starting gates,

Our refuse spread on agar plates,

Arms confined ... unspeaking mind,

Legs . . like leaden weights.

Bones resorb in disintegrating integument.

Who's running this meticulously monitored experiment?

Lights off and on ... is anybody home?

Does anyone care to know?

Lytes in and out ... I I think I'm gone,

Only to find I'm going on.

My breath would try to fail me.

My clock would stop its time.

To sleep . . . and . . . BLEEP!

I weep. Where are the tubes for my tears?

Gainesville, FL 32610

Katherine L. Phaneuf, M.D., M.T University of Florida

found guilty, and seven were hanged. The judges also set forth the Nuremberg Code, a 10-point declaration governing human experimentation that was based on "principles of the law of nations as they result from the usages established among civilized peoples, from the laws of humanity, and from the dictates of public conscience." ${ }^{1}$ The first and best-known principle provides that the voluntary, competent, informed, and understanding consent of the subject is "absolutely essential." There is no exception for soldiers or for wartime, and until Desert Shield, the U.S. military had never argued that there should be such an exception. Current U.S. statutory law also requires that informed consent be obtained for all "investigational use" of drugs, except when the investigators consider it "not feasible, or in their professional judgment, contrary to the best interests of such human beings." 3

In the fall of 1990, after the invasion of Kuwait by Iraq, the Department of Defense sought a waiver of the consent requirements in the Food and Drug Administration's existing regulations governing human experimentation so that the military could administer investigational drugs and vaccines to the Desert Shield soldiers without their informed consent. The justification for the request was military expediency. In the words of the Department of Defense request: "In all peace time applications, we believe strongly in informed consent and its ethical foundations ... but military combat is different." "The department argued that informed consent under combat conditions was "not feasible" because some troops might refuse to consent, and the military could not tolerate such refusals because of "military combat exigencies." 4 The FDA granted the request and issued a new general regulation, rule $23(\mathrm{~d}),{ }^{5}$ that permits waivers on a drug-by-drug basis on the grounds that consent is "not feasible in a specific 
military operation involving combat or the immediate threat of combat." 4

Shortly after the new regulation was promulgated, and just before Desert Storm, a suit was brought by the Public Citizen Health Research Group on behalf of an unnamed soldier (John Doe) and his wife to enjoin the Department of Defense from using drugs on troops in the Persian Gulf without consent, on the basis of rule $23(\mathrm{~d})$. At that time, the FDA had granted waivers under rule $23(\mathrm{~d})$ for the use of two agents, pyridostigmine bromide $(30-\mathrm{mg}$ tablets, as a pretreatment for nerve-gas attacks) and pentavalent botulinum-toxoid vaccine (to protect against botulism in biologic warfare).

\section{The Decision of the District Court}

U.S. District Court Judge Stanley Harris made it clear that he had no desire to become involved in military matters. In his words, "The [Defense Department's] decision to use unapproved drugs is precisely the type of military decision that courts have repeatedly refused to second-guess." ${ }^{6} \mathrm{He}$ characterized the decision as one intended to protect individual servicemen and servicewomen, and as "strategic" in nature and thus not subject to review by a court. He went on, however, to say that if he thought he had the authority to review the decision, he would uphold it.

Consistent with the Nuremberg Code, the Defense Department Authorization Act prohibits the Department of Defense from using any of its funds "for any research involving a human being as an experimental subject" unless the subject's informed consent has been obtained. ${ }^{7}$ This restriction was enacted in response to U.S. Army experiments at the beginning of the Cold War in which servicemen were exposed to radiation or given lysergic acid diethylamide (LSD) ${ }^{2}$ Judge Harris, however, decided that "the primary purpose of administering the drugs is military, not scientific," and therefore that the statutory prohibition was inapplicable. ${ }^{6}$

The "not feasible" exception to the consent requirement had previously been applied only to subjects who were unable to communicate, unconscious, or incompetent. Nonetheless, Judge Harris decided that the FDA could reinterpret this exception as long as its interpretation was not "arbitrary, capricious or manifestly contrary to the statute." ${ }^{6}$ Finally, he rejected the claim that forced administration of unapproved drugs violates the Fifth Amendment interest of servicepersons in not being experimented on without their consent. Instead, he found that the military's interest in preventing injury to troops and "successfully accomplishing the military goals of Operation Desert Storm" were sufficient to justify the exception to the regulations on informed consent. The Nuremberg Code was not mentioned in the decision.

\section{The Decision of the Court of Appeals}

"John Doe" appealed. At the hearing, held in March 1991, a letter was introduced from the Department of Defense to the FDA saying that the military requirement for the use of the two agents without in- formed consent had ended. The department also informed the FDA that "Central Command has recently reported that the military command in the theater of operations decided to administer the vaccine on a voluntary basis. The pyridostigmine tablets were used without prior informed consent." The Justice Department argued that because of the end of the war and the Defense Department letter, the case was moot and should be dismissed by the U.S. Gircuit Court of Appeals.

The majority of the court, in a two-to-one opinion written by Judge Ruth Ginsburg in July, disagreed. ${ }^{8}$ The court concluded that even though the Department of Defense had withdrawn its two specific waivers, rule $23(\mathrm{~d})$ remained in effect and the situation could therefore arise again. The court relied heavily on government reports concerning the proliferation of nuclear, chemical, and biologic weapons systems, especially among Third World nations such as Iraq. On the merits, the Court of Appeals disagreed with the lower court that the case was beyond the scope of court review because it was military in nature. Instead, the court defined the issue as a challenge to the FDA's authority to issue a waiver of its consent regulations to the Department of Defense, not as an action challenging military decisions. The Court of Appeals did, however, agree with all the other conclusions of the lower court. Again, no mention was made of the Nuremberg Code. ${ }^{8}$

Judge Clarence Thomas, then a member of the appeals court, filed a dissenting opinion. He agreed with the Justice Department, arguing that because the war was over and because it was virtually impossible for John Doe to be subjected to the rule again, the case should be dismissed as moot. He said that the majority "surely overstates" the risk of future chemical warfare, noting that "after all, American soldiers have not been the victims of organized chemical attack since the First World War." ${ }^{8}$ Judge Thomas also stressed that there was no "reasonable likelihood that John Doe personally" would be involved in any future war involving chemical weapons. In his words, "the majority focuses on Rule 23(d) in the abstract - and in the process forgets about Doe, the plaintiff." 8

Ironically, all Judge Thomas' arguments support the proposition that the rule should never have been promulgated in the first place: the risk of chemical and biologic warfare in the Gulf seems to have been overstated, and the proper concern should focus on individual soldiers, whom the military (and the FDA) had succeeded in treating as merely the means to accomplish a mission.

\section{The Implications of the Decisions}

Since the time of Cicero, it has been said that inter arma leges silentae sunt - amid the clash of arms the laws are silent. This was certainly true during the forced internment of Japanese-Americans from the West Coast during World War II, ${ }^{9}$ and it was true of the courts in this recent case as well. While troops are in the field, courts are unlikely to make any decisions that appear to be interfering with the military. This 
evidence of realpolitik is disturbing, but not surprising. The brief history of international human rights has, after all, been written primarily in the aftermath of war: the founding of the United Nations in 1946, the International Declaration of Human Rights in 1948 , and current efforts to foster human rights in the wake of the Cold War. Neither of the courts in the Doe case was likely to discuss the Nuremberg Code because the waiver rule is a clear violation of it, and acknowledging this violation could have embarrassed the United States. We might have appeared hypocritical because at the time these cases were heard, members of the administration were calling for a Nuremberg-style tribunal to try Saddam Hussein and his military leaders for violations of international law. International human-rights laws must, of course, apply to both victors and vanquished.

Even though rule $23(\mathrm{~d})$ authorizes the violation of the Nuremberg Code, it can be argued persuasively that the code itself was not actually violated during Operation Desert Storm. According to this argument, the code applies only to experimentation or research on human beings, and the Defense Department was not conducting research. This was not, after all, anything like the Army's infamous secret experiments with radiation and LSD in the 1950 s and 1960 s. $^{2}$ What was at stake in the case of the pyridostigmine bromide tablets was the use of an approved drug for an unapproved reason. Such use can be justified in certain circumstances and could even be considered treatment if nerve-gas attack appeared imminent, as it did to the commander of the XVIII Airborne Corps whose 4l,650 soldiers took the drug for one to seven days at eight-hour intervals. ${ }^{10}$

Members of the military have no right to refuse any medical treatment that can make them fit for combat or return them to active duty. The reason it is legally acceptable to require combat troops to be treated if treatment can return them to active duty is that it would be impossible to have an effective armed force if refusals of treatment could be used as a way to avoid combat or other risky assignments. The distinction between treatment and experimentation (or research) may seem arbitrary - and at the margin, it often is but it is based on the following rationale. Treatment is given for the benefit of the individual patient, rather than for the benefit of society or a researcher, and when sufficient data are available to determine whether the intervention is likely to be helpful or harmful to that patient. Historically, "nontherapeutic experimentation" on healthy volunteers has been the model for research, whereas "therapeutic experimentation" on patients is more and more seen simply as therapy. Thus, if pyridostigmine is a treatment, requiring its use does not violate the Nuremberg Code. ${ }^{11,12}$

I think this argument is correct, even though data from Desert Storm were collected and analyzed, ${ }^{10}$ and that it was unnecessary for the Defense Department to ask for a waiver of the requirement for informed consent by research subjects to administer this agent. The Court of Appeals should have used this rationale for its decision. The Army, Navy, and Air Force seem also to have agreed with this view, since they were prepared to dispense pyridostigmine to troops long before the waiver was even sought. ${ }^{13}$

It is much more difficult, however, to make the same argument in the case of botulinum-toxoid vaccine. This vaccine had been used by about 3000 laboratory workers in the past, but its use was discontinued in the mid-1970s (before sufficient data on safety and efficacy had been gathered to qualify it for licensure) and few laboratory workers have used it since. It remains an unapproved agent, and the Centers for Disease Control have an elaborate consent form that explains its experimental nature as an investigational new drug. The reason the military did not violate the Nuremberg Code in giving this vaccine to troops is not that it can be legitimately considered treatment or therapy, but that it was decided to give the troops in the Persian Gulf the right to refuse to be vaccinated. This decision merits commendation, and it would be interesting to know more about how and why military commanders in the field chose not to take advantage of their legal authority to give this vaccine to the troops without consent. No matter what their motivation, however, I believe that they were correct. They may indeed have taken the principles of the Nuremberg Code more seriously than did the Department of Defense, the FDA, or the two courts in the case.

As the Court of Appeals noted, the Department of Defense had argued in court that these agents had not previously been tested in controlled clinical trials "because humans cannot intentionally be exposed to chemical or biological [warfare] agents in order to test the effectiveness of a drug." 8 This is true, primarily because such exposure violates another dictate of the Nuremberg Code: "No experiment should be conducted where there is an a priori reason to believe that death or disabling injury will occur." 'General Norman Schwarzkopf and his medical command seem to have understood that one cannot pick and choose which items of the Nuremberg Code to take seriously.

\section{The Role of Military Physicians}

What should physicians in the military do when asked to administer investigational agents without the informed consent of the soldiers? Even if such administration is legal (as the courts have ruled), many would find it unethical, and as the Nuremberg trials affirmed, "following orders" is no excuse for unethical conduct, even in combat. The only justification a physician could have for participating in the administration of experimental or investigational agents without soldiers' consent is that he or she sincerely believes the agents are therapeutic under combat conditions. This is, of course, a difficult position to take, since war does not change the nature of a drug or vaccine. Such a decision would also be contrary to military regulations, which hold that, although a serviceperson must accept standard medical treatment or face court-martial, soldiers have no obligation to accept interventions that are not generally recognized by the medical profession as standard procedures. ${ }^{14,15}$ 
A related question is whether a military physician is primarily responsible for the health and well-being of the soldiers under his or her care (as in civilian life) or whether he or she must subordinate the medical interests of soldier-patients to the military mission. Remarkably, there is no written policy or standard view on this question in the military. The issue deserves critical attention in peacetime, since it is not susceptible to rational analysis in wartime. An unequivocal policy upholding traditional patient-centered ethics, although not legally required, seems the most responsible position for U.S. military physicians who do not serve in combat positions to take.

The experience with rule 23(d) during Operation Desert Storm illustrates the difficulty of making distinctions between experimental interventions and treatment, the difference between law (especially as enunciated by the courts during wartime) and ethics, and the potential conflicts between the best interests of a physician's patients and the interests of a physician's employer. Although it was designed to resolve these conflicts, rule $23(\mathrm{~d})$ primarily served to highlight them, and to reverse a 44-year policy of following the Nuremberg Code. The rule not only turned out to be militarily unnecessary but also called into question the seriousness of the United States' human-rights agenda.

\section{REFERENCES}

1. Trials of war criminals before the Nuremberg Military Tribunals. Tribunal I. Case I. The military case: United States of America v. Karl Brandt et al. Vol. 2. Washington, D.C.: Government Printing Office, 1950.

2. Annas GJ, Grodin MA, eds. The Nazi doctors and the Nuremberg Code: human rights in human experimentation, New York: Oxford University Press, 1992:61-129, 188-208.

3. 21 U.S.C. sec. $355(\mathrm{i})$.

4. Informed consent for human drugs and biologics; determination that informed consent is not feasible. Fed Reg 1990;55:52, 814-7.

5. 21 C.F.R. sec. 50.23(d).

6. Doe v. Sullivan, 756 F. Supp. 12 (D.D.C. 1991)

7. 10 U.S.C. sec. 980.

8. Doe v. Sullivan, 938 F.2d 1370 (D.C. Cir. 1991)

9. Currie DP. The Constitution in the Supreme Court: the second century, 1888-1986. Chicago: University of Chicago Press, 1990:280-307.

10. Keeler JR, Hurst CG, Dunn MA. Pyridostigmine used as a nerve agent pretreatment under wartime conditions. JAMA 1991;266:693-5.

11. Waivers for military use of investigational agents. Am J Hosp Pharm 1991;48:1525-9.

12. Howe EG, Martin ED. Treating the troops. Hastings Cent Rep 1991;21(2): 21-8.

13. Treatment of chemical agent casualties and conventional military chemical injuries; FM 8-285, NAVMED P-5041, AFM 160-11. Washington, D.C.: Headquarters, Departments of the Army, the Navy, and the Air Force, February 1990:sec. 2-15-2-19.

14. Johnson WH. Civil rights of military personnel regarding medical care and experimental procedures. Science 1953;117:212-5.

15. United States v. Stanley, 483 U.S. 669 (1987).

\section{OCGASIONAL NOTES} TO END AN EPIDEMIC

\section{Lessons from the History of Diphtheria}

ONE hundred years ago, diphtheria was predicted to be "the scourge of America in the future." $\mathrm{Al}$ though this prediction was realized, diphtheria has since become only a chapter in the history of American public health, and the acquired immunodeficiency syndrome (AIDS) has emerged as the scourge of the future. Every epidemic disease is in some ways unique, but none is wholly so, and the history of diphtheria may be relevant today.

Diphtheria was the first infectious disease to be conquered on the basis of the principles of microbiology and public health. It emerged as a threat at a time when the understanding of infectious disease was prescientific, and epidemics of diphtheria continued as scientific advances began to offer both explanation and hope. The disease evoked fear and brought stigma; it was attributed by some to divine retribution. And diphtheria spread mysteriously because of asymptomatic carriers who were unaware that they were contagious. As forms of technology were developed to diagnose and treat diphtheria, quarantine and population testing became prominent in the public

Supported in part by a grant from the Robert Wood Johnson Foundation. The views and opinions expressed herein are those of the author and do not necessarily reflect those of the foundation.

Presented in part at the Region IX-X Meeting of the Ambulatory Pediatric Association, Carmel, Calif., February 4, 1991, and the Southern California Regional Meeting of the Society for General Internal Medicine, Los Angeles, April 17, 1991 . health response. Diphtheria proved unusually disruptive of the normal doctor-patient relationship. Some doctors justified turning away patients with diphtheria by noting the increased mortality from the disease among the children of physicians. In turn, especially before the discovery of effective therapy, many parents were reluctant to bring their children to the doctor when they had symptoms of diphtheria because of a reluctance to submit to quarantine or a fear of compulsory admission to a hospital ward, where mortality from heroic therapy could exceed 80 percent. ${ }^{2-5}$

\section{History of Diphtheria}

Before the 19th century, diphtheria was strictly an epidemic disease. The largest outbreak among North American settlers occurred from 1735 to 1740 in the New England colonies; 1 person in 40 died of diphtheria during that time - the vast majority of them children. ${ }^{6}$ Its mysterious origin and the slow, suffocating death it caused contributed to its terror. In 1736, one clergyman was moved to write, "We are led to look beyond natural causes to the Hand of God." He concluded, "The Death of many Children before they were arriv'd to Years of Discretion, shews the woful Effects of Original Sin." 7

Over the next century, diphtheria became endemic in American cities and thus became a familiar, if unwelcome, companion to urban dwellers, another hardship of 19th-century life. In the 1880s, Klebs and Löffler independently identified the diphtheria bacillus. ${ }^{8}$ American physicians became convinced of this cause in $18919^{9,10}$ Klebs was working at the Pasteur Institute and Löffler in Koch's laboratories when 